\title{
KREATIFITAS MASYARAKAT DALAM DIVERSIFIKASI OLAHAN JAGUNG SERTA PEMANFAATAN MEDIA SOSIAL SEBAGAI SARANA PROMOSI PRODUK
}

\author{
Community Creativity in Diversification of Maize Processes and The Use of Social Media \\ as The Promotion of Product
}

\author{
Cahyuni Novia $^{1)}$, Syaiful ${ }^{1)}$, dan Deny Utomo ${ }^{2)}$ \\ ${ }^{1)}$ Sekolah Tinggi Teknologi Nurul Jadid Probolinggo \\ ${ }^{2)}$ Fakultas Pertanian, Universitas Yudharta Pasuruan \\ email : denyut369@gmail.com
}

\begin{abstract}
Sidodadi Village is a village located in Paiton Sub-district of Probolinggo Regency of East Java Province. Sidodadi Village is one of the biggest corn-producing villages in Paiton Subdistrict, Probolinggo District. The potential of corn crops in Sidodadi Village is still very good, the production of corn crops on average once harvest yields 15 to 20 tons. The goal to be achieved in community service activities is to increase the income of the community groups of mothers PKK through corn processing afkir into chips/ tortillas and dodol. The method is done by using lecture and demonstration method along with the training material, and delivered directly by performing pendemontrasian with respect to the process of making dodol and chips / tortillas ranging from raw materials, how to use the means of production, the process of mixing the materials, cooking until packaging. Working partners' results can make tortillas and maize dodol and can do packing well.
\end{abstract}

Keywords: corn, tortilla chips, dodol

\begin{abstract}
ABSTRAK
Desa Sidodadi adalah sebuah desa yang terletak di Kecamatan Paiton Kabupaten Probolinggo Propinsi Jawa Timur. Desa Sidodadi merupakan salah satu desa penghasil jagung terbesar di Kecamatan Paiton Kabupaten Probolinggo. Potensi tanaman jagung yang ada di Desa Sidodadi ini masih sangat bagus, produksi tanaman jagung rata-rata sekali panen menghasilkan 15 sampai dengan 20 ton. Tujuan yang ingin dicapai dalam kegiatan pengabdian kepada masyarakat ini adalah meningkatkan pendapatan masyarakat kelompok ibu-ibu PKK melalui pengolahan jagung afkir menjadi keripik / tortilla dan dodol. Metode yang dilakukan dengan menggunakan metode ceramah dan demonstrasi disertai materi pelatihan, serta disampaikan langsung dengan melakukan pendemontrasian yang berkenaan dengan proses pembuatan dodol dan tortilla mulai daripenanganan bahan baku, cara penggunaan alat-alat produksi, proses pencampuran bahan, pemasakan sampai pengemasan. Hasil secara keseluruahan mitra kerja dapat membuat keripik/tortilla dan dodol jagung afkir serta dapat melakukan pengemasan dengan baik.
\end{abstract}

Kata kunci : Jagung, keripik jagung, dodol 


\section{PENDAHULUAN}

Desa Sidodadi adalah sebuah desa yang terletak di Kecamatan Paiton Kabupaten Probolinggo Propinsi Jawa Timur. Desa Sidodadi merupakan salah satu desa peng-hasil jagung terbesar di Kecamatan Paiton Kabupaten Probolinggo. Potensi tanaman jagung yang ada di Desa Sidodadi ini masih sangat bagus, produksi tanaman jagung rata-rata sekali panen menghasilkan 15 sampai dengan 20 ton.

Jagung (Zea mays L.) merupakan tanaman pokok yang menyediakan $60 \%$ dari total produksi pangan dunia (Nuss dan Tanumihardjo, 2010) dan makanan ketiga yang paling penting dari dunia setelah gandum dan padi (Aydinsakir et al., 2013). Jagung sebagian besar terdiri dari karbohidrat, sebagian besar dalam bentuk pati, dengan cukup jumlah protein serta beberapa lipid, vitamin, dan mineral. Jagung memiliki komposisi protein sebesar $8-12 \%$, serat kasar $0,8-2,5 \%$ dan $68-73 \%$ karbohidrat (Ullah et al., 2010). Jagung mempunyai banyak manfaat salah satunya untuk mencegah kanker (Jayaram et al., 2015).

Jagung merupakan salah satu tanaman pangan yang sangat penting dan strategis dalam upaya pembangunan pertanian di Indonesia karena menjadi salah satu tanaman pokok bagi kebutuhan manusia (Widiyanti et al., 2016). Dalam usaha meningkatkan daya guna jagung, maka perlu dilakukan diversifikasi pengolahan produk pangan asal jagung. Produk pangan yang dimaksud merupakan bahan olahan setengah jadi maupun bahan siap dikonsumsi. Bahan olahan tersebut harus disukai oleh konsumen dan secara ekonomis pengolahan bahan tersebut mempunyai efisiensi yang tinggi. Jagung juga dapat dikembangkan menjadi produk yang bernutrisi dan bernilai jual tinggi selain itu tentunya akan mempunyai masa simpan lebih panjang jika dikemas dengan baik (Agato dan Narsih, 2011). Hasil panen dari tanaman jagung tidak semuanya bagus, melainkan ada yang isi bijinya tidak rata atau ukurannya kecil dan jika dijual harganya sangat murah, biasanya petani jagung didaerah sidodadi menyebutnya dengan sebutan jagung afkir.

Salah satu hasil olahan jagung yang disukai konsumen pada saat ini adalah keripik jagung atau tortilla (Sánchez-Madrigal et al., 2014). Proses pengolahan produk ini cukup sederhana sehingga berpeluang diadopsi oleh masyarakat pedesaan, terutama wanita tani sebagai industri rumah tangga (Agato dan Narsih, 2011). Makanan ringan berbahan baku dasar jagung adalah keripik dan dodol jagung juga sangat mempunyai potensi yang sangat besar untuk dikembangkan. Dodol jagung merupakan makanan tradisional yang cukup populer di beberapa daerah di Indo-nesia, dapat diolah dari tepung ketan, tepung biji-bijian, palawija maupun buah-buahan dicampur dengan gula atau diberi tambahan bahan lain seperti tepung beras atau tepung ketan, tepung tapioka, tepung hunkwe, bahan pewarna maupun bahan lainnya. Cara pembuatan dodol sangat mudah, peralatan yang digunakan juga sederhana sehingga dapat diterapkan sebagai industri rumah tangga (Wahyuni et al., 2014; Utomo et al., 2014; Novia et al, 2015).

Permasalahan utama masyarakat di Desa Sidodadi adalah belum mengenal teknologi pengolahan jagung afkir. Sebagian besar produksi jagung di daerah ini hanya dijual dalam bentuk segar dengan harga yang sangat murah dan biasanya dipergunakan untuk direbus ataupun dijadikan lauk dan sayur. Sebagian lagi biasanya dikeringkan untuk dijadikan pakan ternak. Harga jagung afkir sering kali dibawah harga pasar yaitu Rp 1.500 - Rp 1.900/kg.

Hal ini terjadi karena ketidakpahaman masayarakat setempat tentang jenis produk lain yang dapat dihasilkan dari bahan baku jagung afkir, masyarakat juga belum memahami teknologi sederhana apa yang dapat diaplikasikan pada jagung afkir yang mereka miliki. Mereka beranggapan bahwa jagung hanya bisa jual dalam bentuk segar (belum diolah) dan dikeringkan saja. Padahal hanya dengan sentuhan teknologi yang sederhana jagung afkir dapat menjadi produk olahan yang bernilai tinggi di- 
bandingkan dengan menjual dalam bentuk belum diolah. Salah satunya adalah mengolah jagung afkir menjadi keripik (tortilla chips) dan dodol.

Lambannya akses informasi yang masuk kepedesaan dan kurangnya kepedulian masyarakat terhadap perkembangan teknologi membuat masyara-kat ketinggalan informasi-informasi penting yang telah dan sedang berkembang, termasuk informasi penting mengenai teknologi tepat guna sederhana yang dapat diterapkan pada kehidupan sehari-hari. Selain itu tingkat pendidikan juga berpengaruh terhadap pola pikir kehidupan mayarakat sehingga kreasi-kreasi baru sulit mereka ciptakan dan dikembangkan. Sarana dan prasarana yang kurang, letak yang jauh dari kota juga merupakan suatu hambatan dalam penerimaan teknologi terbaru. Kenyataan inilah yang terjadi pada seluruh masyarakat pedesaan termasuk masyarakat petani jagung di desa Sidodadi Kecamatan Paiton, Kabupaten Probolinggo.

Permasalahan lainnya adalah peningkatan produksi jagung pada saat panen raya sebesar $16,5-22$ ton (10\%) dengan harga jual jagung bahkan sampai Rp.750,$/ \mathrm{kg}$, sehingga harga tersebut lebih murah lagi dan sangat jauh dari harga normal. Kondisi tersebut memaksa para petani jagung untuk tetap menjual jagung afkir dalam bentuk segar karena terdesak oleh kebutuhan, bahkan ditemukan juga jagung yang tidak dijual, tetapi dijadikan pakan ternak. Ditinjau dari aspek sosial budaya masyarakat setempat, banyaknya jagung afkir yang tidak terjual atau hanya menjadi pakan ternak sangat dipengaruhi oleh kebiasaan dari petani pendahulunya dan belum adanya sarana prasarana yang memadai dalam mengakses informasi secara cepat.

Perubahan perilaku masyarakat yang sedang digemari adalah penggunaan media social sebagai sarana komunikasi juga telah sampai di masyarakat desa Sidodadi. Tetapi mereka belum memanfaatkan media tersebut untuk sarana promosi, hanya sebagai media komunikasi saja. Sarana Promosi produk dengan dengan mengguna-kan media social. Menurut Hidayatullah (2016), media sosial adalah sebuah media online dimana penggunanya bisa dengan mudah ber-partisipasi, berbagi dan menciptakan isi meliputi blog, social net-work atau jejaring social (face book, Twitter, Instagram dsb), wiki, forum dan dunia virtual. Sosial media yang paling banyak digunakan adalah blog, social network atau jejaring sosial (face book, twitter, instagram dan sebagainya) dan wiki.

\section{BAHAN DAN METODE}

\section{Bahan}

Bahan keripik meliputi, jagung kualitas afkir, tepung tapioka, air, garam, bawang putih dan gula. Bahan pembuatan dodol meliputi, jagung afkir, santan, gula, garam, margarine, dan tepung ketan.

\section{Alat}

Alat yang digunakan adalah Blender, Penggiling daging (untuk menghaluskan jagung), gilingan mie (cetakan keripik), pemarut kelapa, sealer, dandang, kompor, pisau, talenan, sutil, bak penampungan bahan, wajan, sendok pengaduk, nampan cetakan, sepet, dan plastik kemasan.

\section{Metode pelaksanaan penelitian}

Metode pengumpulan data dilakukan dengan melakukan wawancara pada pengurus PKK dan masyarakat. Pengumpulan data ini dimaksudkan untuk mengetahui status sosial, pendidikan dan motivasi mitra kerja dalam kegiatan IbM yang dilaksanakan agar target luaran dapat tercapai.

Target luaran dinilai pada saat pelaksanaan kegiatan praktek pembuatan keripik dan dodol jagung afkir dan pemantauan keberlanjutan kegiatan dengan memanfatkan media soaial sebagai sarana promosi produk. 


\section{HASIL DAN PEMBAHASAN}

Hasil pelaksanaan kegiatan Pengabdian kepada masyarakat melibatkan dua mitra. Mitra kerja yang ikut dalam kegiatan pelatihan pembuatan produksi dan pengemasan adalah 25 orang dengan distribusi pendidikan 8 orang SMU, 8 orang SMP dan 6 orang SD. Secara umum, pendidikan mitra kerja cukup baik dan data yang ditemui menunjukkan bahwa tidak ada seorang pun dari peserta yang pernah mengetahui cara pembuatan keripik dan dodol jagung afkir.

Tabel 1. Mitra kerja yang pernah membuat keripik dan dodol sebelum kegiatan IbM

\begin{tabular}{lcc}
\hline & Keripik & Dodol \\
\hline Pernah & 0 & 0 \\
Belum & 25 & 25 \\
pernah & & 25 \\
\hline
\end{tabular}

Rendahnya pengetahuan pasca panen jagung afkir mitra kerja dengan berlimpahnya bahan baku jagung afkir di desa Sidodadi merupakan fenomena yang menarik perhatian tim kerja untuk melatih dan mentransfer pengetahuan pembuatan keripik dan dodol jagung afkir. Tabel 1 memperlihatkan jumlah mitra kerja yang pernah membuat keripik dan dodol jagung afkir sebelum kegiatan IbM dilaksanakan

Tabel 2. Produk yang dihasilkan menarik, dapat dikembangkan dan bernilai jual

\begin{tabular}{ccc}
\hline & Keripik & Dodol \\
\hline Ya & 25 & 16
\end{tabular}

Tidak

0

Jumlah

25

25

Mitra kerja yang berjumlah 25 orang belum pernah membuat keripik dan dodol jagung afkir (Tabel 1). Setelah melaksanakan kegiatan, ternyata $100 \%$ mitra kerja dapat membuat produk keripik dan dodol jagung afkir dengan baik yaitu secara fisik dan rasa keripik dan dodol menarik sehingga dapat dikembangkan sebagai produk pasca panen jagung afkir yang memberikan alternatif jagung dijual dalam bentuk segar (Tabel 2). Kondisi produk akan lebih menarik dan ketahanan produk meningkat dengan dilakukan pengolahan dan pengemasan yang benar.

Tabel 3. Mitra kerja yang pernah memanfaatkan media sosial sebagi sarana promosi produk

\begin{tabular}{lcc}
\hline & Keripik & Dodol \\
\hline Pernah & 0 & 0 \\
Tidak & 25 & 25 \\
Jumlah & 25 & 25 \\
\hline
\end{tabular}

Peralatan pengemasan yang dimiliki mitra kerja menjadi modal penting dalam pengembangan produk dan peningkatan nilai jual keripik dan dodol jagung afkir. Dasar dalam pengembangan produk yaitu bahan dasar yaitu jagung afkir sangat mudah didapatkan di desa Sidodadi. Produk keripik dan dodol jagung afkir juga relatif mudah di buat oleh mitra kerja pada saat pelatihan produksi dan saat peninjauan keberlanjutan kegiatan. Saat membuat keripik dan dodol, tim pelaksana memberikan alternatif dan penjelasan yang mendasar serta sederhana. Penjelasan tersebut berkenaan dengan mitra kerja yang akan mengkonsumsi produk yang dibuat. Pemanfaatan media sosial sebagai sarana promosi produk juga belum pernah dilakukan oleh peserta pelatihan, Karena para peserta masih banyak yang tidak mengetahui aplikasi di hp yang dapat digunakan untuk mempromosikan produk.

\section{KESIMPULAN}

Dua tahapan kegiatan pengabdian kepada masyarakat yang telah dilakukan dapat disimpulkan bahwa: 
1. Seluruh mitra kerja dapat membuat keripik dan dodol jagung afkir serta melakukan pengemasan dengan baik.

2. Produk keripik dan dodol jagung afkir yang dihasilkan pada pelatihan produksi menarik dan dapat dikembangkan.

3. Bahan dasar pembuatan produk keripik dan dodol, yaitu jagung afkir yang mudah didapatkan di desa Sidodadi.

\section{UCAPAN TERIMA KASIH}

Penulis mengucapkan terima kasih kepada seluruh pihak yang telah membantu dalam pelaksanaan kegiatan Ibm dan seluruh pihak yang telah membantu dalam penelitian ini terutama kepada DPRM Dikti, STT Nurul Jadid, dan Kelompok Ibu-ibu PKK Desa Sidodadi Kabupaten Probolinggo.

\section{DAFTAR PUSTAKA}

Agato \& Narsih. (2011). Pengembangan hasil pertanian (jagung) menjadi produk susu jagung dan kerupuk jagung. Jurnal Teknologi Pangan 2(1): 86-94.

Aydinsakir, K., Erdal S., Buyuktas D., Bastug R. \& Toker R. (2013). The influence of regular deficit irrigation applications on water use, yield, and quality components of two corn (Zea mays L.) genotypes. Agricultural Water Management 128: 65-71.

Hidayatullah, N. (2016). Promosi penjualan melalui jejaring sosial (Studi deskriptif kualitatif promosi penjualan melalui jejaring sosial twitter pada "coffee house ulee kareng"). Flow, 2(18).

Jayaram, S., Kapoor S. \& Dharmesh S M. (2015). Pectic polysaccharide from corn (Zea mays L.) effectively inhibited multi-step mediated cancer cell growth and metastasis. Chemicobiological Interactions, 235: 63-75.
Novia, C., Syaiful \& Utomo D. (2015). Diversifikasi mangga off grade menjadi dodol dan dodol. Teknologi Pangan 6(2) : 76-79.

Nuss, E. T. \& Tanumihardjo S. A. (2010). Maize: a paramount staple crop in the context of global nutrition. Comprehensive Reviews in Food Science and Food Safety 9(4): 417436.

Sánchez-Madrigal, M. Á., MeléndezPizarro, C. O., Martínez-Bustos, RuizGutierrez, M.G. Qiuntero- Ramos A, Márquez-Meléndez, R., \& CamposVenegas, K. (2014). Structural, functional, thermal and rheological properties of nixtamalised and extruded blue maize (Zea mays L.) flour with different calcium sources. International Journal of Food Science \& Technology 49 (2): 578-586.

Ullah, I., Ali M. \& Farooqi A. (2010). Chemical and nutritional properties of some maize (Zea mays L.) varieties grown in NWFP, Pakistan. Pakistan journal of Nutrition 9(11): 1113-1117.

Utomo, D., Wahyuni R. \& Novia C. (2014). Diversifikasi produk olahan apel manalagi kualitas afkir menjadi dodol dan dodol. Jurnal Agrika 8(2) : 211217.

Wahyuni, R., Utomo D., Novia, C. \& Syaiful. (2015). Peningkatan nilai ekonomis wortel kualitas afkir menjadi krupuk dan dodol. Cyber Techn 9(2) : 53-57.

Widiyanti, N. M. N. Z., Baga, L. M. \& Suwarsinah H. K. (2016). Kinerja usahatani dan motivasi petani dalam penerapan inovasi varietas jagung hibrida pada lahan kering di Kabupaten Lombok Timur. Jurnal Penyuluhan 12(1): 31-42. 